\title{
Effects of Pruning and Cluster Thinning on Yield and Fruit Composition of 'Chambourcin' Grapevines
}

\author{
S. Kaan Kurtural ${ }^{1}$, Imed E. Dami², and Bradley H. Taylor ${ }^{3}$
}

AdDitional INDEX wORDs. balanced cropping, crop level, French-American hybrid, total soluble solids

Summary. Response of yield components and fruit composition of 'Chambourcin' (Vitis vinifera $\times$ V. rupestris) grapevines to three pruning levels of 15, 20, and 25 nodes retained for each pound of dormant prunings; and three cluster thinning levels of 1, 2, and 2+ clusters per shoot in 2002 and 1, 1.2, and 1.5 clusters per shoot in 2003 were measured at two vineyards in the lower midwestern United States. In both years of the study, there was very little interaction of pruning and cluster thinning. The proportion of non-count shoots increased within the canopy in response to increased pruning severity. Pruning weight means were lower in 2002 across all treatments compared to 2003. Pruning weights decreased with the increase in the number of clusters retained per vine. Pruning influenced yield only in 2003 when the proportion of count shoots decreased below $62 \%$ of the total, hence the relationship between number of shoots per vine and yield $\left(\mathrm{R}^{2}=\right.$ $0.3452 ; P<0.0003$ ). In both years of the study, the increase in severity of cluster thinning resulted in yield reduction but an increase in the total soluble solids in juice. Yield compensation was achieved by an increase in cluster weight of $38 \%$, and $25 \%$ in response to a reduction of $37 \%$, and $23 \%$ in cluster numbers; which translated into a yield reduction of only $10 \%$ and $3 \%$, at Vineyards 1 and 2, respectively. Balanced pruning to 15 to 20 nodes per $1 \mathrm{lb}$ of prunings and cluster thinning to 1 to 1.2 clusters/shoot optimized yield $\left(9.7 \mathrm{~kg} / \mathrm{vine}, 13.4 \mathrm{t} \cdot \mathrm{ha}^{-1}\right)$ and fruit composition, and maintained vine size $\left(\geq 0.3 \mathrm{~kg} \cdot \mathrm{m}^{-1}\right.$ of row $)$. These results provide valuable information for growers of 'Chambourcin' grapevines in the lower midwestern U.S., as well as in other climates with long growing seasons.

$\mathrm{C}$ hambourcin' is an important red wine grape cultivar in southern Illinois due to its adaptability to climate and soil and increased local demand (Dami et al., 2001). However, there is insufficient experience and horticultural research on grapevine canopy and crop level management for sustainable production of 'Chambourcin' under the long growing season of the lower midwestern U.S.

Department of Horticulture, N308D Agricultural Science Building-North, University of Kentucky, Lexington, KY 40546-0091

We gratefully acknowledge the cooperation of Alto Vineyards, Alto Pass, Ill., and Goshen Trail Vineyards, Dix, Ill., during the project. This project was funded in part by the Illinois Grape and Wine Resources Council housed at Southern Illinois University.

${ }^{1}$ State Viticulturist; to whom reprint requests should be addressed. E-mail address: k.kurtural@uky.edu

${ }^{2}$ Assistant Professor and Viticulture Specialist, Department of Horticulture and Crop Science, Ohio Agricultural Research and Development Center, 1680 Madison Avenue, Wooster, OH 44691-4096.

${ }^{3}$ Associate Professor and Pomology Specialist, Department of Plant, Soil and Agricultural Systems, 1205 Lincoln Dr., PSAS 4415, Southern Illinois University, Carbondale, IL 62901-4415.
Grapevine crop control is commonly accomplished via balanced pruning (Partridge, 1925). In native American cultivars such as 'Concord' (Vitis labruscana), balanced pruning was achieved by retaining 30 buds for the first $1 \mathrm{lb}$ of dormant prunings removed and 10 additional buds for each additional pound of dormant prunings, and resulted in optimum yield and fruit composition (Morris and Cawthon, 1980; Shaulis and Oberle, 1948; Shaulis and Robinson, 1953). However, balanced pruning alone does not adequately control crop level of
French-American hybrids (Howell et al., 1987; Kaps and Cahoon, 1989). For example, 'Chambourcin' produces a large number of fruitful shoots from non-count positions (Ferree et al., 2003). The fruitfulness of non-count buds is the primary cause of overcropping and ineffectiveness of balanced pruning (Ferree et al., 2003; Pool et al., 1978). In order to remedy this problem and regulate cropping levels in several hybrid cultivars, such as 'Vidal blanc' and 'Seyval blanc', balanced pruning and cluster or berry thinning have been used in tandem (Howell et al., 1987; Kaps and Cahoon, 1989; Shaulis et al., 1953).

Cluster thinning is a technique used to obtain the needed crop control in French-American hybrids (Fisher et al., 1977; Kaps and Cahoon, 1989). Thinning to two clusters per shoot reduced yield, but increased the total soluble solids of the grape juice at harvest and was found to invigorate the vine in following years in a number of French-American hybrid and $V$. vinifera cultivars (Bravdo et al., 1984; Nonnecke, 1980; Reynolds et al., 1986). Kaps and Cahoon (1989) reported acceptable crop reduction in 'Seyval blanc' grapevines with either berry or cluster thinning where yield was reduced but fruit quality was improved. For 'Vidal blanc', cluster thinning to one cluster per shoot and a balanced pruning formula of $15+10$ was advised based on labor cost savings and minimized crop loss due to winter damage in Michigan (Howell et al., 1987). These results coupled with improved fruit quality and periderm browning of potted 'Chambourcin' led to a new concept, "balanced cropping," where both balanced pruning and cluster or shoot thinning are used in tandem for crop adjustment of French-American hybrids that can also be achieved mechanically (Miller et al., 1996; Morris et al., 2004).

\begin{tabular}{lllc}
\hline $\begin{array}{l}\text { Units } \\
\text { To convert U.S. to SI, } \\
\text { multiply by }\end{array}$ & U.S. unit & SI unit & $\begin{array}{l}\text { To convert SI to U.S., } \\
\text { multiply by }\end{array}$ \\
\hline 29.5735 & $\mathrm{fl} \mathrm{oz}$ & $\mathrm{mL}$ & 0.0338 \\
0.3048 & $\mathrm{ft}$ & $\mathrm{m}$ & 3.2808 \\
25.4 & inch $(\mathrm{es})$ & $\mathrm{mm}$ & 0.0394 \\
0.4536 & $\mathrm{lb}$ & $\mathrm{kg}$ & 2.2046 \\
1.1209 & $\mathrm{lb} / \mathrm{acre}$ & $\mathrm{kg} \cdot \mathrm{ha}^{-1}$ & 0.8922 \\
1.4882 & $\mathrm{lb} / \mathrm{ft}$ & $\mathrm{kg} \cdot \mathrm{m}^{-1}$ & 0.6720 \\
28.3495 & $\mathrm{oz}$ & $\mathrm{g}$ & 0.0353 \\
0.001 & $\mathrm{ppm}$ & $\mathrm{g} \cdot \mathrm{L}^{-1}$ & 1000 \\
2.2417 & ton $/ \mathrm{acre}$ & $\mathrm{t} \cdot \mathrm{ha}^{-1}$ & 0.4461 \\
$\left({ }^{\circ} \mathrm{F}-32\right) \div 1.8$ & ${ }^{\circ} \mathrm{F}$ & ${ }^{\circ} \mathrm{C}$ & $\left(1.8 \times{ }^{\circ} \mathrm{C}\right)+32$ \\
& & &
\end{tabular}


Growers in southern Illinois have had to rely on viticultural information generated in Michigan and New York. However, macroclimatic conditions in these regions are characteristics of cool climate viticulture (Jackson and Schuster, 1987) with growing degree days (GDD) of 1250 GDD (base $10^{\circ} \mathrm{C}$ ) and 1275 GDD, respectively (Howell, 2001). Southern Illinois is characterized by warm climate viticulture with more than 2200 GDD (Angel, 2003). It is hypothesized that cropping targets of 'Chambourcin' are not similar in cool vs. warm climate conditions.

The goal of this study was to identify optimal combinations of balanced pruning and cluster thinning levels without adversely affecting yield components and fruit composition of 'Chambourcin' for sustainable grape production in southern Illinois and the lower midwestern U.S. The specific objectives were to determine the effect of pruning and cluster thinning on vegetative growth, yield components, and fruit composition of 'Chambourcin' grapevines.

\section{Materials and methods}

Plant material and site. This study was conducted in 2002 and 2003 at two commercial vineyards (designated as Vineyard $\mathrm{l}$ and Vineyard 2 ), planted with own-rooted 'Chambourcin' grapevines at $2.4 \times 3.0 \mathrm{~m}$ (vine $\times$ row) spacing. Vineyard 1 was located in Alto Pass, Ill. (lat. $37.58^{\circ} \mathrm{N}$, long. $89.32^{\circ} \mathrm{W}, 233.4 \mathrm{l} \mathrm{m}$ absolute elevation) and planted in 1984 on Alford silt-loam soil, a fine-silty, mixed, superactive, mesic Ultic Hapludalf. Vineyard 2 was located in Dix, Ill. (lat. $38.45^{\circ} \mathrm{N}$, long. $89.04^{\circ} \mathrm{W}, 176.73$ $\mathrm{m}$ absolute elevation), and planted in 1997 on Newberry silt-loam soil, a finesilty, mixed, superactive, mesic Mollic Endoaqualf. Vines were trained to a 6-ft-high bilateral-cordon. The vines were supplied with $67 \mathrm{~kg} \cdot \mathrm{ha}^{-1}$ nitrogen annually and were not irrigated. The experiment was a $3 \times 3$ factorial treatment arrangement in a completely randomized design (CRD) with four replications. Each experimental unit consisted of three vines.

Pruning treatments. Previous year's (2001) canes were pruned to five-node canes to an upper limit of 65 nodes per vine. The prunings were weighed (data not shown) and the number of nodes to be left on the vine in 2002 was then determined by the weight of the cane prunings removed. The buds at these nodes are referred to hereafter as count-buds. The three levels of pruning severity selected were $(15+15),(20+20)$, and $(25+25)$. Level numbers refer to number of buds left for the initial $\mathrm{l} \mathrm{lb}$ of prunings, plus number of buds retained for each additional pound of prunings.

Cluster thinNing TREATMents. Three levels of cluster thinning were established 2 to 3 weeks post-bloom (3- to 5-mm-diameter berry size) in 2002 and 4 weeks post-bloom (berrytouch) in 2003. The number of clusters per shoot and per vine was counted prior to thinning in both years. In 2002 , the cluster thinning treatments consisted of retaining one (thinned to basal cluster), two, or all clusters per shoot. In 2003, the cluster thinning treatments were adjusted to retaining $1,1.2$, and 1.5 clusters per shoot. A maximum target number of clusters (60 clusters/vine) was established in 2003 to avoid overcropping (>60 clusters/vine) obtained in 2002 .

SHOOT COUNTS AND PRUNING wEIGHTS. At bud burst, total shoots and nodes that did not produce a shoot were counted. Count shoots (borne from count-buds retained at pruning $>5 \mathrm{~mm}$ distal to the base of the cane), non-count shoots (borne from basal buds $<5 \mathrm{~mm}$ distal to the base of the cane or on wood older than 1 year), and total shoots (count + noncount shoots) retained per vine were measured in both years. Vegetative growth in each season was estimated by measuring pruning weight per vine, referred to as vine size. During the growing season, shoots were vertically positioned downward every 14 $\mathrm{d}$ to reduce intra-vine shading. No leaf removal was conducted in the fruit zone.

YIELD COMPONENTS AND FRUIT COMPosition. Fruit yield and cluster numbers for all treatments were measured on a single-treatment replicate (each experimental unit), and all treatments were harvested on the same date. Harvest dates were $12 \mathrm{Sept}$. 2002 and 12 Sept. 2003 at Vineyard I, and 17 Sept. 2002 and 29 Sept. 2003 at Vineyard 2. A random 100-berry sample was collected from each treatment-replicate, placed in polyethylene bags, stored on ice, and analyzed within $24 \mathrm{~h}$. Before analysis, the 100-berry sample was weighed and average berry size was determined. The samples were then crushed by hand and the juice was placed in $100-\mathrm{mL}$ beakers. A 5-mL portion of each sample was used to determine the percent total soluble solids (TSS) using a digital refractometer (Spec Scientific Ltd., Scottsdale, Ariz.) The juice $\mathrm{pH}$ was determined with a glass electrode and a pH meter (model AR15; Fisher Scientific, Pittsburgh). The acidity of each sample was determined by titrating to $\mathrm{pH} 8.2$ with $0.1 \mathrm{~N}$ sodium hydroxide and expressed as grams per liter tartaric acid (TA) (Iland et al., 2002).

STATISTiCal anAlYses. Standard CRD analysis of variance analyses (ANOVA) were performed using the Type III tests of fixed effects with the MIXED procedure of SAS (version 8.1; SAS Institute, Cary, N.C.), after all the assumptions for ANOVA had been met (Wilcox, 2001). Treatment means were separated by Tukey's honestly significant difference test at $P \leq 0.05$. Treatments were then tested for polynomial trends across treatment levels using the GLM procedure of SAS. Simple linear regression analyses using the REG procedure of SAS were used to conduct regression analyses where appropriate.

\section{Results}

EFFECT OF PRUNING ON NODES RETAINED AND SHOOT NUMBERS. The pruning treatments imposed affected the number of nodes retained on the vines (Table 1 ). The number of nodes retained increased linearly as the severity of pruning declined in both vineyards and years. In 2003, the number of nodes retained at Vineyard 1 was reduced by $45 \%$ compared to 2002 due to the reduced amount of prunings collected (Table 1). The pruning treatments imposed affected the number of total shoots borne in both vineyards and years (Fig. 1). There was a linear increase in the number of total shoots per vine as the severity of pruning decreased in both vineyards and years. In 2002, the increase in the proportion of count shoots per vine had the most effect on the total number of shoots per vine. In 2002, the noncount shoots accounted for $25 \%$ and $32 \%$ of the total shoots at Vineyard 1 and Vineyard 2, respectively (Fig. 1). In 2003, the non-count shoots accounted for $43 \%$ and $34 \%$ of the total shoots at Vineyard 1 and Vineyard 2, respectively (Fig. 2). The proportion of non-count shoots in 2003 increased 
Table 1. Average number of nodes retained and dormant pruning weights per vine of 'Chambourcin' grapevines as affected by pruning and cluster thinning treatments at two commercial vineyards. ${ }^{\mathrm{z}}$

\begin{tabular}{|c|c|c|c|c|c|c|c|c|}
\hline \multirow[b]{3}{*}{$\begin{array}{l}\text { Pruning } \\
\text { formula }^{\mathrm{y}}\end{array}$} & \multicolumn{4}{|c|}{2002} & \multicolumn{4}{|c|}{2003} \\
\hline & \multicolumn{2}{|c|}{ Vineyard 1} & \multicolumn{2}{|c|}{ Vineyard 2} & \multicolumn{2}{|c|}{ Vineyard 1} & \multicolumn{2}{|c|}{ Vineyard 2} \\
\hline & $\begin{array}{c}\text { Nodes } \\
\text { (no./vine) }\end{array}$ & $\begin{array}{l}\text { Pruning } \\
\text { wt }(g)^{x}\end{array}$ & $\begin{array}{c}\text { Nodes } \\
\text { (no./vine) }\end{array}$ & $\begin{array}{c}\text { Pruning } \\
\text { wt }(\mathrm{g})\end{array}$ & $\begin{array}{c}\text { Nodes } \\
\text { (no./vine) }\end{array}$ & $\begin{array}{c}\text { Pruning } \\
\text { wt (g) }\end{array}$ & $\begin{array}{c}\text { Nodes } \\
\text { (no./vine) }\end{array}$ & $\begin{array}{c}\text { Pruning } \\
\text { wt (g) }\end{array}$ \\
\hline $15+15$ & $30 \mathrm{c}$ & $411 \mathrm{~b}$ & $19 \mathrm{c}$ & 515 & $15 \mathrm{c}$ & 735 & $21 \mathrm{c}$ & 825 \\
\hline $20+20$ & $35 \mathrm{~b}$ & $445 \mathrm{~b}$ & $27 \mathrm{~b}$ & 592 & $20 \mathrm{~b}$ & 673 & $28 \mathrm{~b}$ & 781 \\
\hline $25+25$ & $45 \mathrm{a}$ & 551 a & $34 \mathrm{a}$ & 608 & $25 \mathrm{a}$ & 733 & $36 \mathrm{a}$ & 827 \\
\hline \multicolumn{9}{|l|}{ Trend ${ }^{\mathrm{w}}$} \\
\hline Linear & 0.0001 & 0.0074 & 0.0001 & 0.0543 & 0.0001 & 0.0609 & 0.0001 & 0.9902 \\
\hline Quadratic & 0.8675 & 0.4096 & 0.4872 & 0.6823 & 0.6472 & 0.4728 & 0.7207 & 0.5904 \\
\hline \multicolumn{9}{|l|}{ Cluster thinning $^{v}$} \\
\hline 1 cluster/shoot & & 533 & & 624 & & 765 & & 866 \\
\hline \multicolumn{9}{|l|}{ Trend } \\
\hline Linear & & 0.0484 & & 0.0502 & & 0.0415 & & 0.0355 \\
\hline Quadratic & & 0.2663 & & 0.3636 & & 0.7207 & & 0.5593 \\
\hline Pruning $\times$ thinning & & 0.9731 & & 0.3277 & & 0.8785 & & 0.9565 \\
\hline
\end{tabular}

${ }^{2} \mathrm{n}=36$; significance for main effects and interaction according to Type III tests of fixed effects.

y $15+15,20+20$, and $25+25$ represent 15,20 , and 25 nodes retained for each pound of dormant prunings removed per vine; $1 \mathrm{lb}=0.4536 \mathrm{~kg}$.

Pruning weight per vine; $1 \mathrm{~g}=0.0353 \mathrm{oz}$.

wTrend response carried to the quadratic level using single df planned orthogonal contrasts.

'In 2002 , the cluster thinning treatments consisted of retaining one (thinned to basal cluster), two or all clusters per shoot. In 2003 , the cluster thinning treatments were adjusted to retaining $1,1.2$, and 1.5 clusters per shoot.

more drastically at Vineyard I (73\% across all pruning treatments) than at Vineyard 2 (6\% across all pruning treatments), due to the drastic reduction in prunings in response to the 2002 treatments.

EFFECT OF PRUNING AND CLUSTER THINNING ON PRUNING WEIGHTS. Pruning treatments imposed did not affect pruning weights in both vineyards and years, except at Vineyard 1 in 2002 (Table 1). Pruning weights increased linearly with the increase in the severity of cluster thinning on both vineyards and years (a nonsignificant linear relationship) (Table 1). In 2002, the pruning weights at Vineyard 1 averaged $0.47 \mathrm{~kg} /$ vine $\left(0.19 \mathrm{~kg} \cdot \mathrm{m}^{-1}\right.$ of row) and were well below the optimum ranges $\left(0.30\right.$ to $0.59 \mathrm{~kg} \cdot \mathrm{m}^{-1}$ of row) (Reynolds and Wardle, 1994; Shaulis and Robinson, 1953; Shaulis et al., 1953). In 2002, pruning weights at Vineyard 2 averaged $0.57 \mathrm{~kg}$ /vine $\left(0.23 \mathrm{~kg} \cdot \mathrm{m}^{-1}\right.$ of row $)$, which are also below the reported optimum ranges for 'Seyval blanc' and 'Concord'. The low pruning weights measured in response to the 2002 treatments affected the number of nodes retained on the vines during the application of pruning treatments in the following year. In
2003 , the pruning weights at Vineyard $\mathrm{l}$ averaged $0.71 \mathrm{~kg} /$ vine $\left(0.30 \mathrm{~kg} \cdot \mathrm{m}^{-1}\right.$ of row $)$, and $0.81 \mathrm{~kg} /$ vine $\left(0.33 \mathrm{~kg} \cdot \mathrm{m}^{-1}\right.$ of row) at Vineyard 2, which were at the low end of the optimum ranges (Table 1).

EFFECT OF PRUNING AND CLUSTER THINNING ON YIELD COMPONENTS. In 2002 , the pruning treatments imposed had little effect on yield components (Table 2). Cluster number-per-vine values measured in 2002 at Vineyard 1 were affected by the pruning treatments imposed, with no apparent trend. Berry weight at Vineyard I increased linearly with the increase in the severity of pruning. In 2003 , pruning treatments imposed affected the yield components at both vineyards (Table $2)$. In 2003 , cluster number per vine and yield per vine increased linearly at both vineyards, with decreasing pruning severity. Cluster weight at both vineyards in 2003 fit a quadratic trend where it was decreased for the $20+20$ pruning treatment compared to $15+15$ and $25+25$ treatments (Table $2)$. In 2002 , there was no association between the total number of shoots retained per vine and yield per vine $\left(\mathrm{n}=72, \mathrm{R}^{2}=0.0094, \mathrm{P}<0.8763\right)$. However, in 2003 there was a posi- tive linear association between total number of shoots retained per vine and yield per vine $\left(\mathrm{n}=72, \mathrm{R}^{2}=0.3452\right.$, $P<0.0003)$. The cluster thinning treatments imposed in 2002 affected yield components (Table 2 ). In 2002, cluster number per vine and yield per vine increased linearly with the decrease in the severity of cluster thinning. The cluster weight at Vineyard 1 decreased linearly with the decrease in the severity of cluster thinning (Table 2). In 2003, cluster number per vine and yield per vine increased linearly with the decrease in the severity of cluster thinning in both vineyards (Table 2 ). The cluster thinning treatments imposed in 2003 did not affect cluster weight in either vineyard.

Clusters retained per vine had the most effect on yield in both years and vineyards. There was a positive linear association in 2002 between clusters per vine and yield per vine $\left(\mathrm{n}=36, \mathrm{R}^{2}\right.$ $=0.8344, P<0.0001 ; \mathrm{n}=36, \mathrm{R}^{2}=$ $0.7960, P<0.0001$; at Vineyard $\mathrm{l}$ and Vineyard 2, respectively). There was a similar association between clusters per vine and yield in 2003, where yield per vine increased linearly with the increase in the cluster number $(\mathrm{n}=36$, $\mathrm{R}^{2}=0.6733, P<0.0001 ; \mathrm{n}=36, \mathrm{R}^{2}$ 

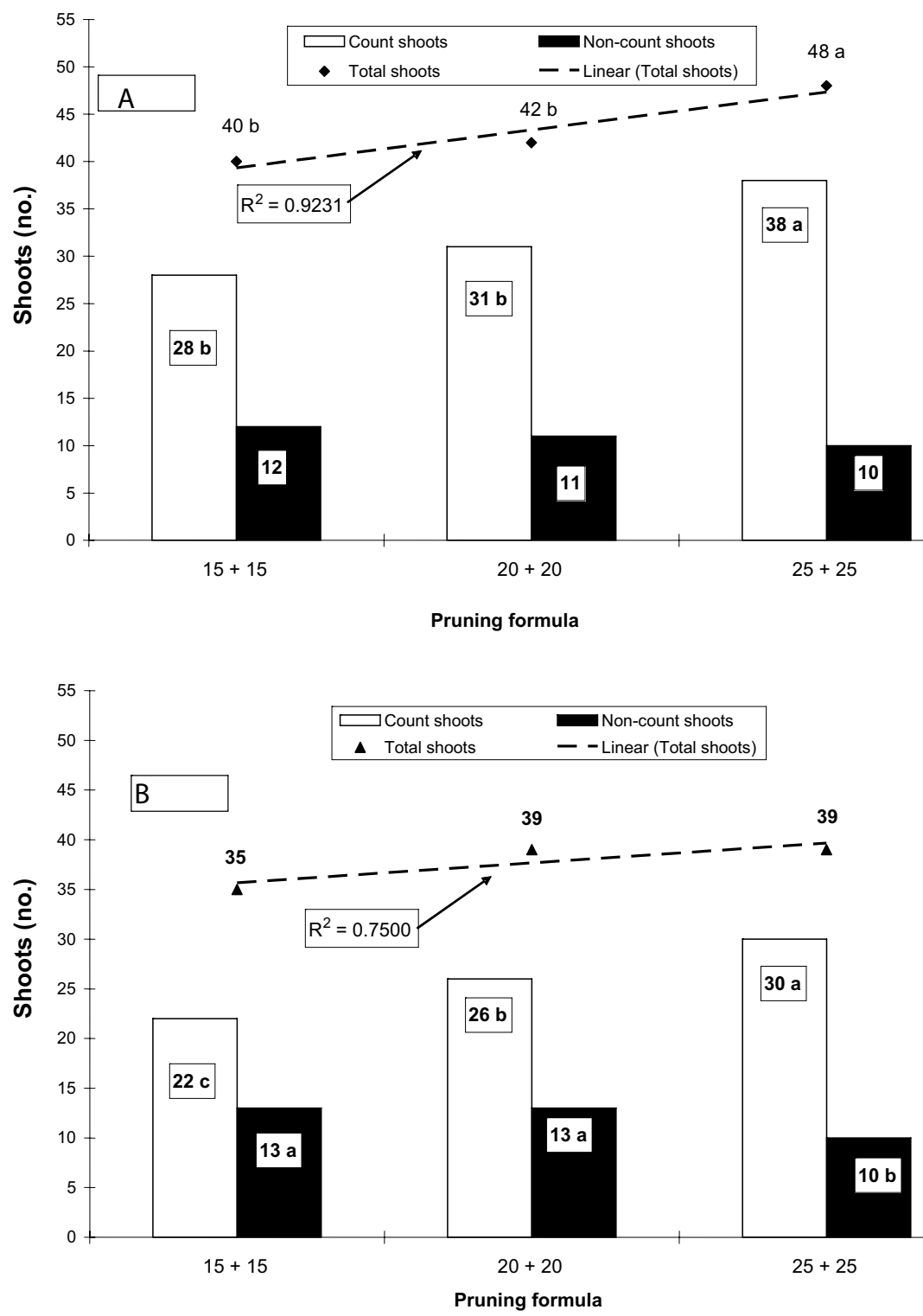

Fig. 1. Effect of pruning treatments on number of count shoots, non-count shoots and total shoots on 'Chamboucin' grapevines at (A) Vineyard 1 and (B) Vineyard 2 in 2002. Pruning formulae $15+15,20+20$, and $25+25$ represent 15 , 20 , and 25 nodes retained for each pound $(0.4536 \mathrm{~kg})$ of dormant prunings removed. Values with different letter designation represent significant mean separation amongst pruning treatments according to Tukey's honestly significant difference test at $P \leq \mathbf{0 . 0 5}$. Linear regressions of number of total shoots are presented with $R^{2}$ values.

$=0.7987, P<0.0001 ;$ at Vineyard 1 and Vineyard 2, respectively).

EFFECT OF PRUNING AND CLUSTER THINNING ON FRUIT COMPOSITION. In 2002, the TSS and $\mathrm{pH}$ were not affected by the pruning treatments imposed (Table 3). The TA increased linearly at Vineyard 2 in 2002 as the severity of pruning increased. In 2003 , the TSS increased linearly at both vineyards with the increase in the severity of pruning (Table 3 ). The $\mathrm{pH}$ only increased at Vineyard 2 in
2003 with the increase in the severity of pruning. The pruning treatments imposed in 2003 did not affect TA at either vineyard. In 2002 and 2003, there was no association between the number of total shoots retained per vine and TSS $\left(\mathrm{n}=72, \mathrm{R}^{2}=0.0091, P\right.$ $<0.9986 ; \mathrm{n}=72, \mathrm{R}^{2}=4.334 \times 10^{-5}, P$ $<0.9995$, respectively). In 2002 , as the severity of cluster thinning increased at both vineyards, TSS and $\mathrm{pH}$ increased linearly (Table 3). In 2002 and 2003, there was a negative linear association between clusters per vine and TSS ( $\mathrm{n}$ $=72, \mathrm{r}=-0.7703, P<0.0001 ; \mathrm{n}=$ $72, \mathrm{r}=-0.6515, P<0.0001$; in 2002 and 2003 , respectively). There was a slight tendency of TA to increase at Vineyard 1 in 2002 with the increase in the severity of cluster thinning. In 2003 , the TSS increased linearly with the increase in the severity of cluster thinning at both vineyards (Table 3 ). In 2003, the cluster thinning treatments imposed did not influence $\mathrm{pH}$ and TA.

\section{Discussion}

EFFECT OF PRUNING AND CLUSTER THINNING ON SHOOT COUNTS AND PRUNING WEIGHTS. Severe pruning reduced the number of count nodes retained on the vines. The reduction of count nodes retained on the vines resulted in a decreased number of count shoots and increased the number of non-count shoots only at Vineyard 2 in 2002, and the difference between treatments was small. Pruning weight was unaffected by varying the shoot density in the canopy as reported by Naor et al. (2002). However, pruning weight increased linearly by controlling the level of crop retained on the vines (Table 1). Research conducted on 'Concord' (Shaulis et al., 1966) and 'Seyval blanc' (Reynolds and Wardle, 1994) determined that pruning weights in excess of $0.59 \mathrm{~kg} \cdot \mathrm{m}^{-1}$ of row are indicative of excessive vine vigor, and pruning weights below 0.30 $\mathrm{kg} \cdot \mathrm{m}^{-1}$ of row are indicative of reduced vine vigor. Using these figures as a guideline, optimal pruning weight is 0.30 to $0.59 \mathrm{~kg} \cdot \mathrm{m}^{-1}$ of row. The mean pruning weight for Vineyard 1 and Vineyard 2 was less than optimum in 2002 due to overcropping, even though Vineyard 1 has been in production 13 years longer than Vineyard 2. Optimal pruning weight in this study was achieved by retaining 1 or 1.2 clusters/shoot.

The clusters retained per vine can also be controlled by increasing the proportion of non-count shoots to count shoots on the vines, as noncount shoots are less fruitful. This is possible with a more severe pruning or shoot thinning. Increasing the severity of pruning in 2003 resulted in a significant relationship between total shoots retained per vine and yield, where the total shoots retained per vine explained $34 \%$ of the total variation in yield per vine. This perhaps 

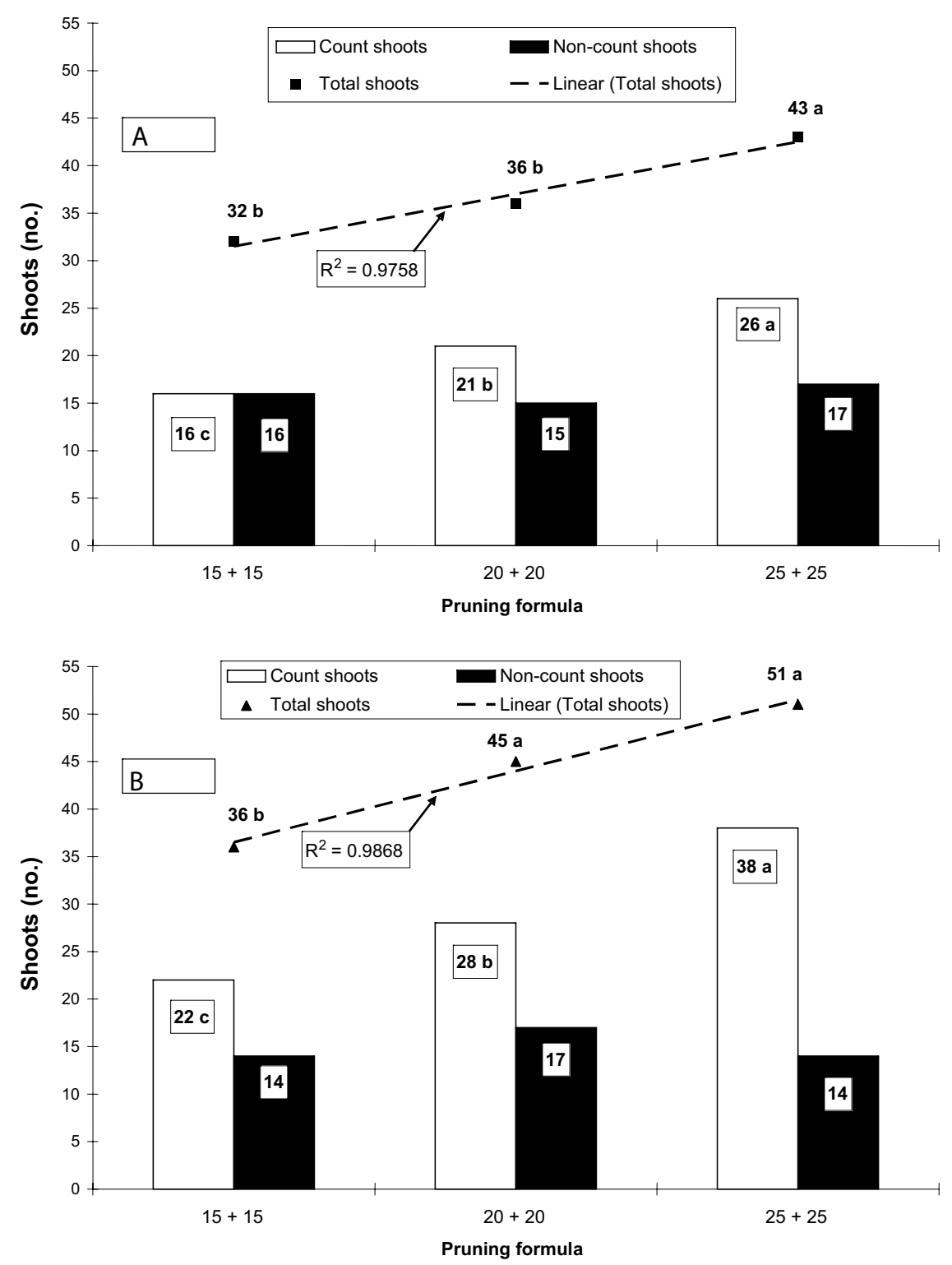

Fig. 2. Effect of pruning treatments on number of count shoots, non-count shoots and total shoots on 'Chamboucin' grapevines at (A) Vineyard 1 and (B) Vineyard 2 in 2003. Pruning formulae $15+15,20+20$, and $25+25$ represent 15 , 20 , and 25 nodes retained for each pound $(0.4536 \mathrm{~kg})$ of dormant prunings removed. Values with different letter designation represent significant mean separation amongst pruning treatments according to Tukey's honestly significant difference test at $P \leq \mathbf{0 . 0 5}$. Linear regressions of total shoots are presented with $\mathbf{R}^{2}$ values.

may reduce labor for cluster thinning where more non-count shoots means fewer clusters, which means less labor to thin.

EFFECT OF PRUNING AND CLUSTER THINNING ON YIELD. In 'Chambourcin', using balanced pruning alone did not result in crop control unless followed by post-fruit set cluster thinning. Balanced pruning affected yield in 2003 only when the proportion of count shoots to total shoots was below $62 \%$. Balanced pruning alone, without cluster thinning, in 'Chambourcin' resulted in overcropping ( 12.4 to $13.7 \mathrm{~kg} /$ vine or 17 to $19 \mathrm{t} \cdot \mathrm{ha}^{-1}$, respectively) and reduction in pruning weights to stressful levels in 2002 in both vineyards. Therefore, balanced pruning alone is not sustainable for 'Chambourcin'. Similar findings were reported for 'de Chaunac', where unthinned vines have often suffered from low vigor and winter injury (Fisher et al., 1977).

In Vineyard 1 and Vineyard 2, the number of clusters retained on the vines explained $75 \%$ and $80 \%$ of the total variance on yield, respectively. Yield was only influenced in 2003 by the total number of shoots retained on the vines with severe pruning. Therefore, yield is primarily affected by the number of clusters retained on the vine.

Overcropping in this study resulted from yields greater than $9.7 \mathrm{~kg} /$ vine $\left(13.4 \mathrm{t} \cdot \mathrm{ha}^{-1}\right)$. The overcropping is detected by the reduction in pruning weight during the same season (i.e., 2002). Decreasing yields from 26 to $12 \mathrm{t} \cdot \mathrm{ha}^{-1}$ in 'Cabernet Sauvignon' by cluster thinning was associated with increased pruning weights (Bravdo et al., 1985). Cluster number was substantially reduced in both vineyards in 2003 , by an average of $37 \%$ reduction at Vineyard 1 and $23 \%$ at Vineyard 2 . This resulted in an average yield reduction of only $10 \%$ and $3 \%$ at Vineyard 1 and Vineyard 2, respectively. Yield compensation in the present study was achieved by a substantial increase in cluster weight of $38 \%$ at Vineyard 1 and $25 \%$ at Vineyard 2. This is an example of yield compensation as reported for other French-American hybrids such as 'Seyval blanc' by Kaps and Cahoon (1989) and Smithyman et al. (1998). In V. vinifera cultivars such as 'Carignane', yield reduction by a medium severity of cluster thinning was slight because the larger berry weight and the number of berries borne per cluster compensated for the reduced number of clusters on the vine (Bravdo et al., 1984). However, with 'Cabernet Sauvignon', only a partial compensation of crop weight was obtained, where the number of berries per bunch was not affected by cluster thinning, and the compensation of the thinned treatments was due to mainly increased berry weight (Bravdo et al., 1985).

Balanced pruning alone did not result in adequate crop control in 'Chambourcin'. Rather, crop was controlled with balanced pruning followed by cluster thinning. Other French-American hybrids, such as 'de Chaunac' (Fisher et al., 1977), Seibel 10878 and Seibel 9110 (Bradt, 1962), 'Vidal blanc' (Howell et al., 1987), and 'Seyval blanc' (Kaps and Cahoon, 1989), have the propensity to overcrop, and crop control was only achieved by the combination of balanced pruning and cluster thinning.

EFFECT OF PRUNING AND ClusTER THINNING TREATMENTS ON FRUIT 
Table 2. Effects of pruning and cluster thinning on average yield components per vine of 'Chambourcin' grapevines at two commercial vineyards. ${ }^{\mathrm{z}}$

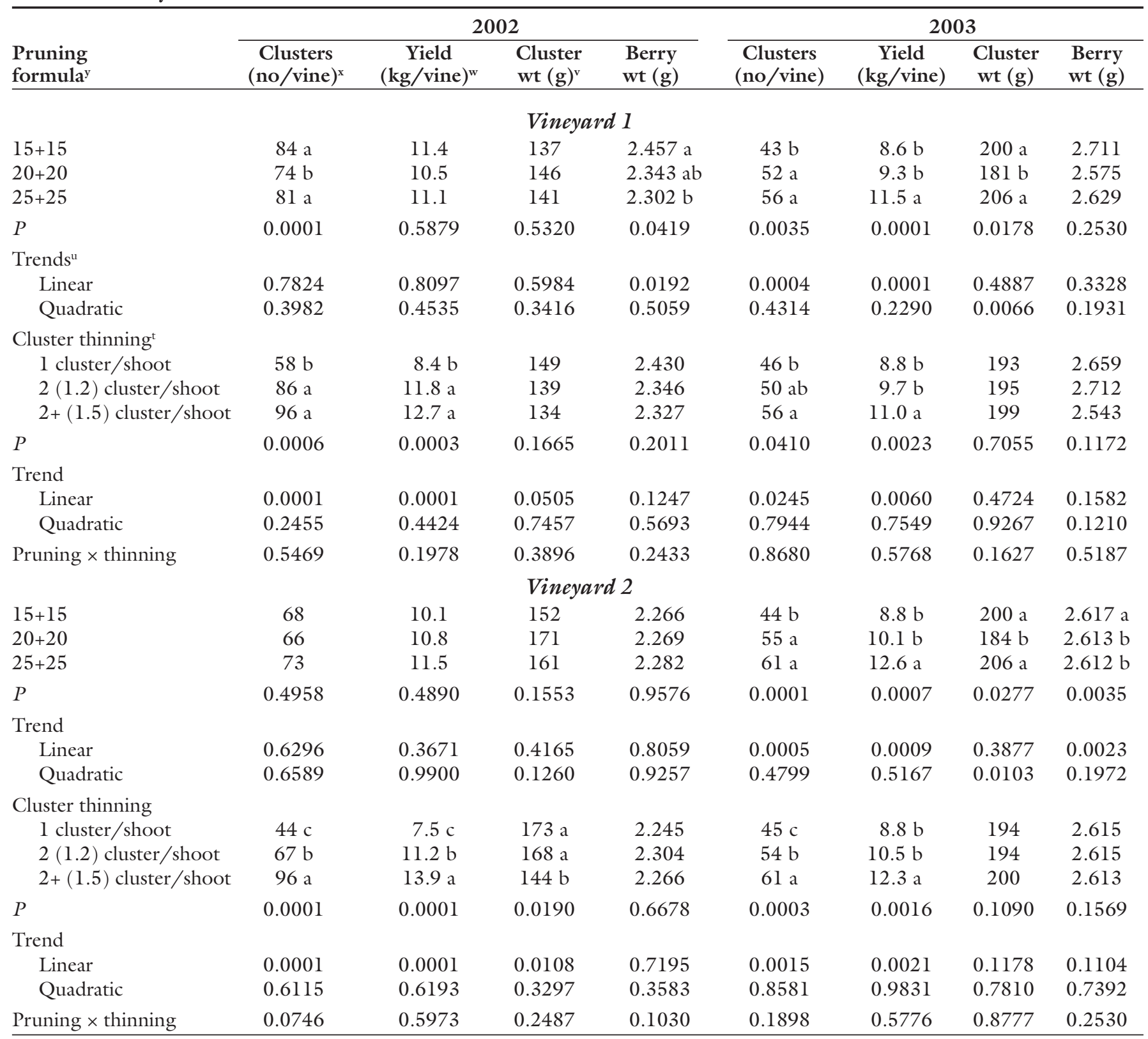

${ }^{\mathrm{z}} \mathrm{n}=36$; significance for main effects and interaction according to Type III tests of fixed effects.

${ }^{y} 15+15,20+20$, and $25+25$ represent 15,20 , and 25 nodes retained for each pound of dormant prunings removed; $1 \mathrm{lb}=0.4536 \mathrm{~kg}$.

'Cluster number harvested per vine.

${ }^{\mathrm{w}} 1 \mathrm{~kg}=2.2046 \mathrm{lb}$.

v $1 \mathrm{~g}=0.0353 \mathrm{oz}$.

"Trend response carried to the quadratic level using single-df planned orthogonal contrasts.

tn 2002, the cluster thinning treatments consisted of retaining one (thinned to basal cluster), two or all clusters per shoot. In 2003 , the cluster thinning treatments were adjusted to retaining $1,1.2$, and 1.5 clusters per shoot.

COMPOSITION. The TSS increased with cluster thinning as reported by others (Bravdo et al., 1984; Miller et al., 1993; Naor et al., 2002). Cluster thinning improved TSS consistently at both vineyards in both years. The clusters retained on the vine explained $59 \%$ and $50 \%$ of the total variation in TSS in 2002 and 2003, respectively. The crop level retained on the vine was the determining factor in fruit composition in 'Chambourcin'. In this experiment, the pooled yield of 2 years from both vineyards explained $23 \%$ of the total variance in TSS, which decreased with increased yields. Similar results on the effects of crop level were reported for high-yielding 'Carignane' vines (Bravdo et al., 1984). For 'Seyval blanc', when crop level was adjusted to 15 clusters per $454.0 \mathrm{~g}$ of cane prunings, post-fruit set, TSS and $\mathrm{pH}$ were enhanced with no difference in TA (Smithyman et al., 1998).

It is concluded that for 'Chambourcin' grown in an environment with a long-growing season and ample heat units, such as southern Illinois and the lower midwestern United States, balanced pruning of 15 to 20 nodes per pound of prunings is recommended. However, balanced pruning needs to be followed by post fruit-set cluster 
Table 3. Effect of pruning and cluster thinning on average fruit composition values per vine of 'Chambourcin' vines at two commercial vineyards. ${ }^{\mathrm{z}}$

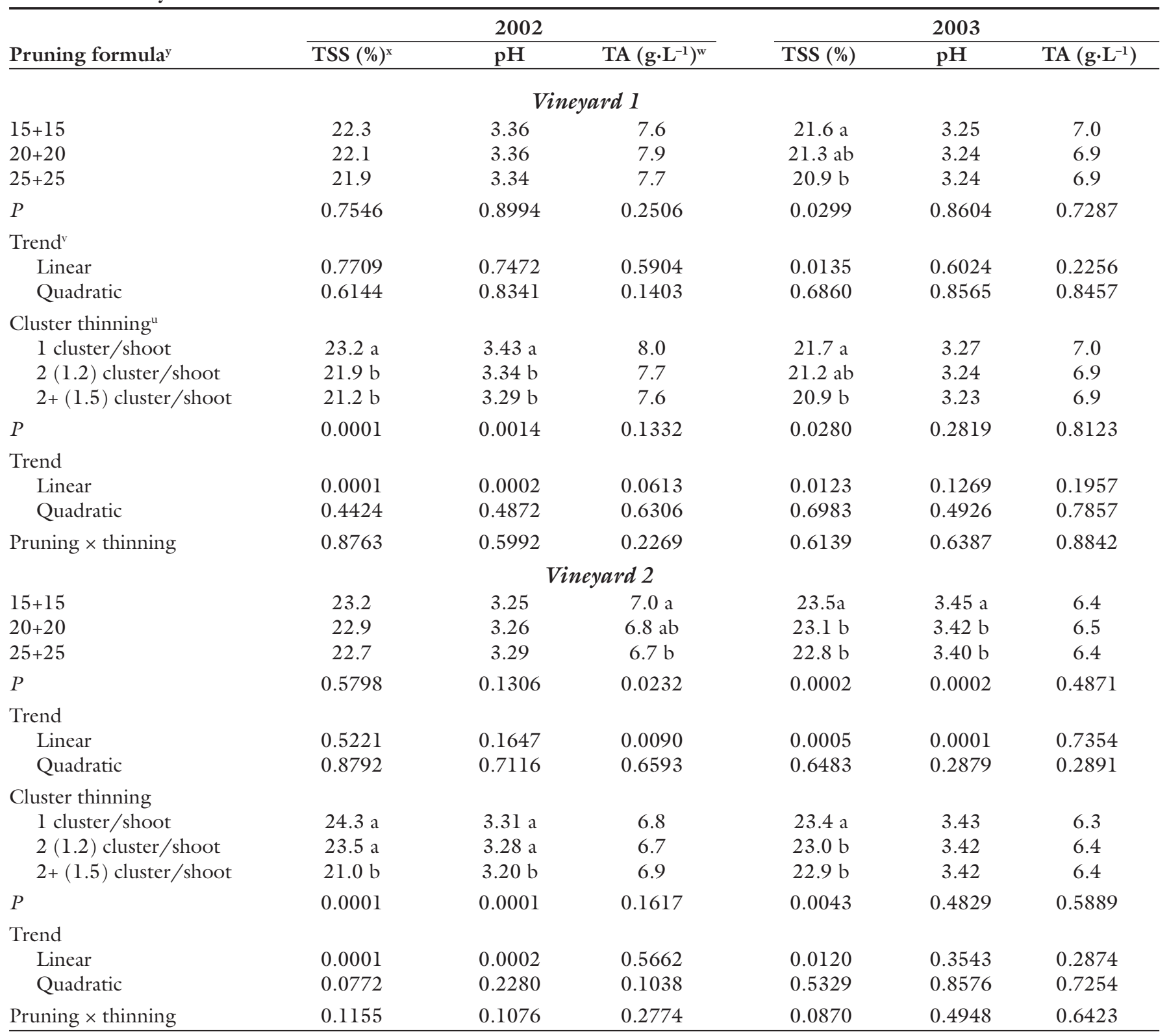

${ }^{2} \mathrm{n}=36$; significance for main effects and interaction according to Type III tests of fixed effects.

${ }^{y} 15+15,20+20$, and $25+25$ represent 15,20 , and 25 nodes retained for each pound of dormant prunings removed; $1 \mathrm{lb}=0.4536 \mathrm{~kg}$.

${ }^{x}$ TSS $=$ total soluble solids measured as percent soluble solids in juice.

wTA $=$ titratable acidity measured as grams of tartaric acid per liter of juice $\left(1 \mathrm{~g} \cdot \mathrm{L}^{-1}=1000 \mathrm{ppm}\right)$.

"Trend response carried to the quadratic level using single-df planned orthogonal contrasts.

un 2002, the cluster thinning treatments consisted of retaining one (thinned to basal cluster), two, or all clusters per shoot. In 2003 , the cluster thinning treatments were adjusted to retaining $1,1.2$, and 1.5 clusters per shoot.

thinning to 1 to 1.2 clusters/shoot. This crop level results in balanced vines with maximum yield (not exceeding 9.7 $\mathrm{kg} /$ vine, $13.4 \mathrm{t} \cdot \mathrm{ha}^{-1}$ ), and optimum fruit composition, and pruning weight $\left(\geq 0.3 \mathrm{~kg} \cdot \mathrm{m}^{-1}\right)$.

\section{Literature cited}

Angel, J. 2003. 1971-2000 Normal annual growing degree days. Illinois State Water Survey, Office of the State Climatologist. 13 Jan. 2006. <http://www.sws.uiuc.edu/ atmos/statecli/Mapsv2/gddl3.gif>.
Bradt, O.A. 1962. Effect of pruning severity and bunch thinning on yield and vigor of Seibel 10878 and Seibel 9110 grapes. Rpt. Hort. Expt. Sta. Prod. Lab. Vineland, Ont. for 1962. p. 19-22.

Bravdo, B., Y. Hepner, C. Loinger, S. Cohen, and H. Tabacman. 1984. Effect of crop level on growth, yield and wine quality of a high yielding 'Carignane' vineyard. Amer. J. Enol. Viticult. 35:247-252.

Bravdo, B., Y. Hepner, C. Loinger, S. Cohen, and H. Tabacman. 1985. Effect of crop level and crop load on growth yield, must and wine composition and quality of 'Cabernet Sauvignon'. Amer. J. Enol. Viticult. 36:125-131.

Dami, I., P. Eberle, and M.R. Brown. 2001. 2000 Illinois vineyard survey. Illinois Grape and Wine Res. Council, Carbondale.

Ferree, D.C., G.A. Cahoon, D.M. Scurlock, and M.V. Brown. 2003. Effect of time of cluster thinning on grapevines. Small Fruit Rev. 2:3-14.

Fisher, K.H., O.A. Bradt, J. Wiebe, and V.A. Kirks. 1977. Cluster thinning 'de Chaunac' 
French hybrid grapes improves vine vigor and fruit quality in Ontario. J. Amer. Soc. Hort. Sci. 102:162-165.

Howell, G.S. 2001. Sustainable grape productivity and the growth-yield relationship: A review. Amer. J. Enol.Viticult. 52:165-174.

Howell, G.S., T.K. Mansfeld, and J.A. Wolpert. 1987. Influence of training system, pruning severity and thinning on yield, vine size, and fruit quality of 'Vidal Blanc' grapevines. Amer. J. Enol. Viticult. 38:105-112.

Iland, P., A. Ewart, J. Sitters, A. Markides, and N. Bruer. 2002. Techniques for chemical analysis and quality monitoring during wine making. Patrick Iland Wine Promotions, Campbelltown, Australia.

Jackson, D. and D. Schuster. 1987. The production of grapes and wine in cool climates. Butterworths, Wellington, New Zealand.

Kaps, M.L. and G.A. Cahoon. 1989. Berry thinning and cluster thinning influence vegetative growth, yield, fruit composition and net photosynthesis of 'Seyval Blanc' grapes. HortScience 114:20-24.

Miller, D.P., G.S. Howell, and J.A. Flore. 1996. Influence of shoot number and crop load on potted Chambourcin grapevines. I. Morphology and dry matter partitioning. Amer. J. Enol. Viticult. 47:380-388.

Miller, D.P., G.S. Howell, and R.K. Striegler. 1993. Reproductive and vegetative response of mature grapevines subjected to differential cropping stress. Amer. J. Enol. Viticult. 44:435-440.
Morris, J.R. and D.L. Cawthon. 1980. Yield and quality response of 'Concord' grapes to training systems and pruning severity in Arkansas. J. Amer. Hort. Soc. Sci. 105:307-310.

Morris, J.R., G.L. Main, and O.L. Oswald. 2004. Flower cluster and shoot thinning for crop control in French-American hybrid grapes. Amer. J. Enol. Viticult. 55:423-426.

Naor, A., Y. Gal, and B. Bravdo. 2002. Shoot and cluster thinning influence vegetative growth, fruit yield and wine quality of Sauvignon blanc grapevines. J. Amer. Soc. Hort. Sci. 127:628-634.

Nonnecke, G.R. 1980. The influence of cluster thinning and shoot-tip removal on 'Seyval' grapevine. PhD Diss., Ohio State Univ., Columbus.

Partridge, N.L. 1925. The fruiting habits and pruning of the 'Concord' grape. Mich. State College Agr. Expt. Sta. Tech. Bul. No. 69.

Pool, R.M., C. Pratt, and H.D. Hubbard. 1978. Structure of base buds in relation to yield of grapes. Amer. J. Enol. Viticult. 29:36-41.

Reynolds, A.G., R.M. Pool, and L.R. Mattick. 1986. Effect of shoot density and crop control on growth, yield, fruit composition and wine quality of 'Seyval' grapes. J. Amer. Hort. Soc. Sci. 111:55-63.

Reynolds, A.G. and D.A. Wardle. 1994. Impact of training system and vine spacing on vine performance and berry composition of Seyval blanc. Amer. J. Enol. Viticult. 45:444-451.
Shaulis, N.J., H. Amberg, and D. Crowe. 1966. Response of Concord grapes to light exposure to Geneva double curtain training. Proc. Amer. Soc. Hort. Sci. 89:268-280.

Shaulis, N.J., K. Kimball, and J.P. Tompkins. 1953. The effect of trellis height and training systems on the growth and yield of 'Concord' grapes under a controlled pruning severity. Proc. Amer. Soc. Hort. Sci. 62:21-227.

Shaulis, N.J. and G.D. Oberle. 1948. Some effects of pruning severity on 'Fredonia' and 'Concord' grapes. Proc. Amer. Soc. Hort. Sci. 51:263-270.

Shaulis, N.J. and W.B. Robinson. 1953. The effect of season, pruning severity and trellising on some chemical characteristics of 'Concord' and 'Fredonia' grape juice. Proc. Amer. Soc. Hort. Sci. 62:214-220.

Smithyman, R.P., G.S. Howell, and D.P. Miller. 1998. The use of competition for carbohydrates among vegetative and reproductive sinks to reduce fruit set and botrytis bunch rot in 'Seyval blanc' grapevines. Amer. J. Enol. Viticult. 49:163-170.

Wilcox, R. 2001. Fundamentals of modern statistical methods: Substantially improving power and accuracy. Springer Verlag, New York. 